\title{
Some Experiences of Resistivity and Induced Polarization Methods on the Exploration of Sulfide: A Review
}

\author{
Claire Dusabemariya', Wei Qian'1, Romuald Bagaragaza ${ }^{2,3}$, Ajibola Richard Faruwa1 ${ }^{1}$, Mossad Ali ${ }^{1}$ \\ ${ }^{1}$ School of Earth Sciences and Engineering, Hohai University, Nanjing, China \\ ${ }^{2}$ College of Water Conservancy and Hydropower Engineering, Hohai University, Nanjing, China \\ ${ }^{3}$ Civil, Environmental and Geomatics Engineering Department, College of Science and Technology, University of Rwanda, \\ Kigali, Rwanda \\ Email: sabeclaire@yahoo.fr, wei.geoserve@gmail.com, bagaromu@yahoo.fr, ajibola.faruwa@gmail.com, \\ mossad_ali2000@aun.edu.eg
}

How to cite this paper: Dusabemariya, C., Qian, W., Bagaragaza, R., Faruwa, A. R., \& Ali, M. (2020). Some Experiences of Resistivity and Induced Polarization Methods on the Exploration of Sulfide: A Review. Journal of Geoscience and Environment Protection, 8, 68-92.

https://doi.org/10.4236/gep.2020.811004

Received: September 27, 2020

Accepted: November 10, 2020

Published: November 13, 2020

Copyright (c) 2020 by author(s) and Scientific Research Publishing Inc. This work is licensed under the Creative Commons Attribution International License (CC BY 4.0).

http://creativecommons.org/licenses/by/4.0/

\begin{abstract}
Sulfide minerals are a group of compounds with the presence of sulfur. This group's most abundant and economically members are pyrites, pyrrhotite, chalcocite, galena, sphalerite, and the group of copper sulfides minerals. Resistivity and Induced Polarization (IP) methods, which play an essential role in mineral exploration, showed great success in sulfide exploration. This paper started on reviewing sulfide formation by giving details which help to understand their genesis better. To make the reader understand the procedures and appropriate mineral exploration methods, we have briefly covered the theory, the basic principles of resistivity and IP methods, and different investigation techniques using one, two, and three-dimensional surveys. Based on many electrical surveys, we discussed with examples of resistivity and IP methods applied to the exploration of sulfide deposits: the data inversion and interpretation of the geophysical signatures of most of the sulfide deposits in various geological environments were analyzed and end by showing both successful surveys and limitations of the methods.
\end{abstract}

\section{Keywords}

Resistivity, Induced Polarization, Chargeability, Sulfides, Mineralization

\section{Introduction}

Sulfide minerals are a group of compounds with the presence of sulfur. The most abundant and economically members of this group are pyrites, pyrrhotite, chal- 
cocite, galena, sphalerite, and the group of copper sulfides minerals (Vaughan \& Corkhill, 2017). It is difficult to distinguish between massive sulfides and other conductors of unknown character and to determine the direction of the orebody (Telford, Geldart, \& Sheriff, 1990b). Electrical Resistivity Tomography (ERT) is the most commonly used geophysical methods for imaging subsurface features and map geological variations. It can detect subsurface sulfide mineral distribution by studying the nature of the flow of electricity in the earth, for being uniquely able to see a large range of magnitudes which can vary up to 20 orders (Morgan, 2012). This method can delineate the various sources of mineralization according to their types (Evrard et al., 2018). The resistivity method is used to map spatial variations in subsurface electrical conductivity, while the induced polarization (IP) method is used to map changes in chargeability.

A variety of applications of resistivity and Induced polarization to mineral exploration were demonstrated in many researchers and significantly prove their success by locating the best drilling points (Langore, Alikaj, \& Gjovreku, 1989; Oldenburg \& Li, 1994; White et al., 2001; Wilkinson et al., 2006; Qian et al., 2007; Bery et al., 2012; Loke et al., 2013; Dandi, 2014; Tavakoli et al., 2016a; Ali et al., 2020). The geological structures of occurrence of sulfide minerals show low resistivity and high chargeability (Johnson \& Anderson, 1981; Langore, Alikaj, \& Gjovreku, 1989; White et al., 2001; Yoshioka \& Zhdanov, 2005; Ja, Oo, \& Arce, 2014; Côrtes et al., 2016). The IP can detect information of small conductive rocks lost in the resistivity models (Tavakoli et al., 2016b). It is also able to detect sulfide in the presence of disseminated mineral deposit (Olowofela, Ajani, \& Oladunjoye, 2008).

This review attempts to provide a clear summary of the success and problems encountered with resistivity and IP methods in sulfide mineral exploration. We focus on determining the efficiency of Resistivity and IP in exploring sulfide minerals by identifying their geophysical properties, the fundamentals of geophysics, and the host rocks by highlighting strengths and weaknesses. It also presents a brief discussion of the limitations of the electrical resistivity and IP methods.

\section{Para Genesis of Sulfides}

Sulfide can be formed abiotically or biogenically.

\subsection{Abiogenic Sulfides Formation}

Sulfide minerals can form abiologically through the crust at high temperatures above about $200^{\circ} \mathrm{C}$ (Plimer \& Finlow-Bates, 1978; Trudinger, 1981; McDonald et al., 2018). High-grade sulfide deposition from abiogenic sulfide exhaled in hydrothermal fluids at oceanic spreading centres and rift zones (Trudinger, 1981). According to McDonald et al. (2018), Three phases are defined: The first is an early-stage of low-temperature $\left(<250^{\circ} \mathrm{C}\right)$, dominated by $\mathrm{Fe}-\mathrm{Zn}$-Cu-rich mineralization, the second stage present high-temperature $\left(>300^{\circ} \mathrm{C}\right)$ and is dominated by $\mathrm{Cu}$-Fe-rich mineralization; and the third is at low-temperature phase $\left(<150^{\circ} \mathrm{C}\right)$ 
dominated by Fe-rich mineralization (McDonald et al., 2018). However, at this low temperature $\left(120^{\circ} \mathrm{C}-140^{\circ} \mathrm{C}\right)$, pyrrhotite can be found in a stable state (Plimer \& Finlow-Bates, 1978).

Figure 1 shows the example of sulfides formation at high temperatures.

The older the deposit and the deeper its site of deposition, the more likely it is to contain abundant pyrrhotite, lack barite (Plimer \& Finlow-Bates, 1978). Deposits which formed at shallow depth $(<500 \mathrm{~m})$ where circulation was probably restricted, pyrite is far more abundant than pyrrhotite (Plimer \& Finlow-Bates, 1978).

\subsection{Biogenic Sulfides Formation}

In biogenic sulfides formation, bacteria activities are the primary source of sulfides. Bacterial sulfate reduction is a potential source of high sulfide concentrations in typical marine sediments. However, fixation is limited by a lack of reactive metals and could lead at best to the formation of relatively low-grade ores. Biogenic sulfide might also contribute to mineralization in hydrothermal situations (Trudinger, 1981). The sulfate reduction process takes place in much lower temperatures $\left(<150^{\circ} \mathrm{C}\right)$ (Trudinger, 1981; McDonald et al., 2018). In hydrothermal systems, thermophilic bacteria biogenically reduce seawater sulfate $\left(\mathrm{SO}_{4}^{2-}\right)$ to sulfide $\left(\mathrm{H}_{2} \mathrm{~S}\right)$ (McDonald et al., 2018). When these react with $\mathrm{Fe}_{2}^{+}$, they can form a very fine particle black precipitates poorly crystalline mackinawite (FeS) or a mixture with greigite $\left(\mathrm{Fe}_{3} \mathrm{~S}_{4}\right)$. With time, these iron minerals transform into pyrite. Figure 2 indicates three possible pathways of transformations.

Table 1 shows examples of sulfide minerals and their host rocks from both abiotically and biogenically.



Figure 1. Genesis of volcanogenic massive sulfide deposits (Galley, 1993; Gibson et al., 2007; Piercey, Peter, \& Herrington, 2015). 


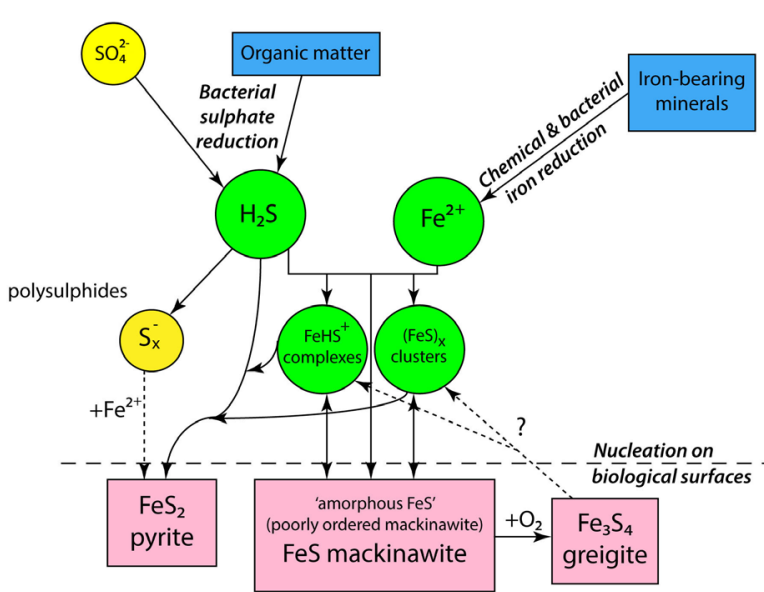

(a)

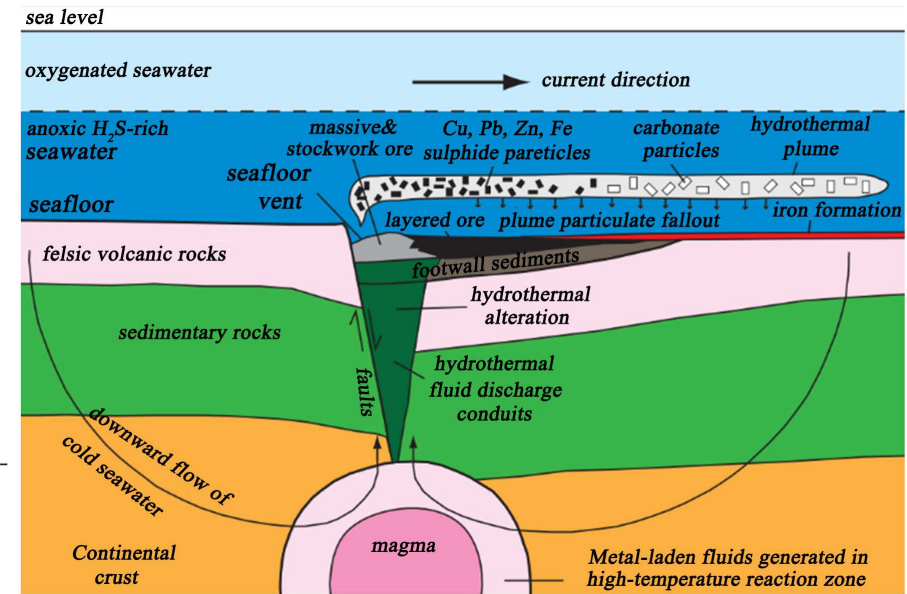

(b)

Figure 2. The pathways leading to the formation of pyrite. Formation of sulfide in Brunswick Number 12 (Piercey, Peter, \& Herrington, 2015; Vaughan \& Corkhill, 2017).

Table 1. The major types of sulfide ore deposits and host rocks.

\begin{tabular}{ccc}
\hline Types & Major ore Minerals & Examples \\
\hline Mafic host rocks & \\
Sulfide nickel deposits & po, pn, py, cpy, vio & Sudbury, Ontario Canada \\
Besshi-type massive sulfides & py, cpy, sph, gn & Japan \\
Finc-lead skarns & pelsic host rocks & \\
Copper skarns & py, gn & Ban Ban, Australia \\
Polymetallic veins & py, cpy, gn, sph, ttd & Camsell River, NWT, Canada
\end{tabular}

Felsic \& mafic host rocks
Creede-type epithermal
Kuroko-type

Quartz pebble

Sandstone-hosted lead-zinc

Sedimentary exhalative lead-zin py, sph, gn, cpy, ttd, asp

py, cpy, gn, sph, ttd, asp

Sedimentary host rocks

U-gold py, uran, gold py, sph, gn

py, sph, gn, cpy, asp, ttd, po

Carbonate host rocks

py, gn, sph
Creede, CO, USA veins

Japan

Witwatersrand, RSA

Laisvall, Sweden

Sullivan, BC, Canada

Abbreviations used are as follows: po-pyrrhotite, pn-pentlandite, py-pyrite, cpy-chalcopyrite, viol-violarite, cass-cassiterite, sph-sphalerite, gn-galena, bn-bornite, ttd-tetrahedrite, asp-arsenopyrite, cinn-cinnabar, uran-uraninite (Fontboté et al., 2017; Vaughan \& Corkhill, 2017).

\section{Theory and Basic Principles of the Resistivity and IP Methods}

\subsection{Theory and Basic Principles of the Resistivity Method}

The electrical resistivity surveys consist of measurement of the resistivity distri- 
bution of subsurface heterogeneities. Electric current is generated into the ground, creating a stationary current flow in the earth. Potentials measured, produce features of the subsurface by providing information on their electrical properties.

For simplicity, all layers are expected to be horizontal. The electrical resistance, $R$ of a material is related to its physical dimension, cross-sectional area, $A$ and length, $L$ through the resistivity, $\rho$.

$$
\rho=R A / L
$$

The electrical resistance of the cylindrical body $R(\Omega)$, is given by:

$$
R=V / I
$$

where $V$ is the potential and $I$ is the current.

The conductivity $\sigma\left(\mathrm{Sm}^{-1}\right)$, is the reciprocal of the resistivity.

$$
\sigma=1 / \rho
$$

(White et al., 2001).

In a homogeneous and isotropic half-space, the current density $J\left(\mathrm{~A} / \mathrm{m}^{2}\right)$ is:

$$
J=I /\left(2 \pi r^{2}\right)
$$

The potential $V$ becomes:

$$
V=(\rho I) /\left(2 \pi r^{2}\right)
$$

The measured voltage with the injected current is converted into apparent resistivity $\left(\rho_{a}\right)$ by a geometric factor which considers the air-earth interface (Telford et al., 1990a)

$$
\rho_{a}=k \frac{\Delta V}{I},[\Omega \cdot \mathrm{m}]
$$

where: $k$ is a geometrical factor $[\mathrm{m}]$.

$$
k=\frac{4 \pi}{\frac{1}{r_{M A}}+\frac{1}{\grave{r}_{M A}}-\frac{1}{r_{M B}}-\frac{1}{\grave{r}_{M B}}-\frac{1}{r_{N A}}-\frac{1}{\grave{r}_{N A}}+\frac{1}{r_{N B}}+\frac{1}{\grave{r}_{N B}}}
$$

$r, \grave{r}$ are the distances of the real and mirror effect of the ground surface at potential points $(M, N)$ respectively.

$\Delta V$ is the measured difference potential at points $M$ and $N ; I$ is the applied electric current.

\subsection{Theory and Basic Principles of the IP Method}

IP has been widely used in geophysical surveys for many decades to provide information about the complex conductivity (chargeability) of the subsurface. IP effect can be measured by both time-domain and the frequency domain. The most common is Time-Domain IP. When the current is applied to the ground, the ground can act as a capacitor and store electric charge. The imposed voltage is switched off; it first drops to an intermediate voltage and then gradually decays (Figure 3 and Figure 4). The polarization characteristics of the subsurface 


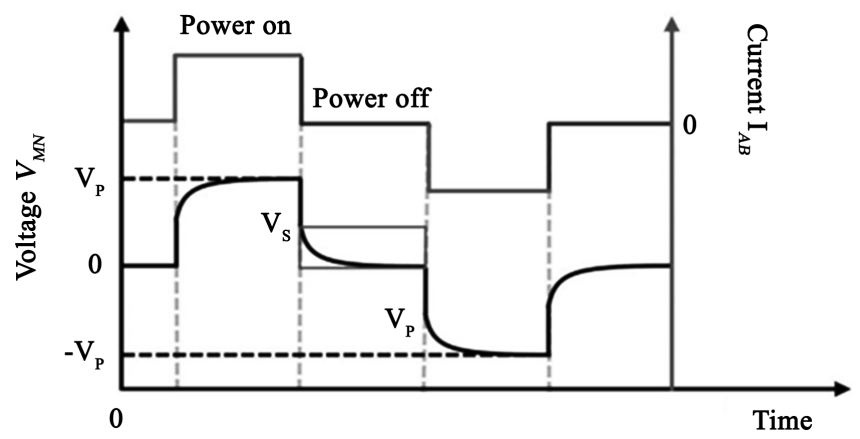

Figure 3. Integrated decay voltage used as a measure of chargeability $\mathrm{m}$.

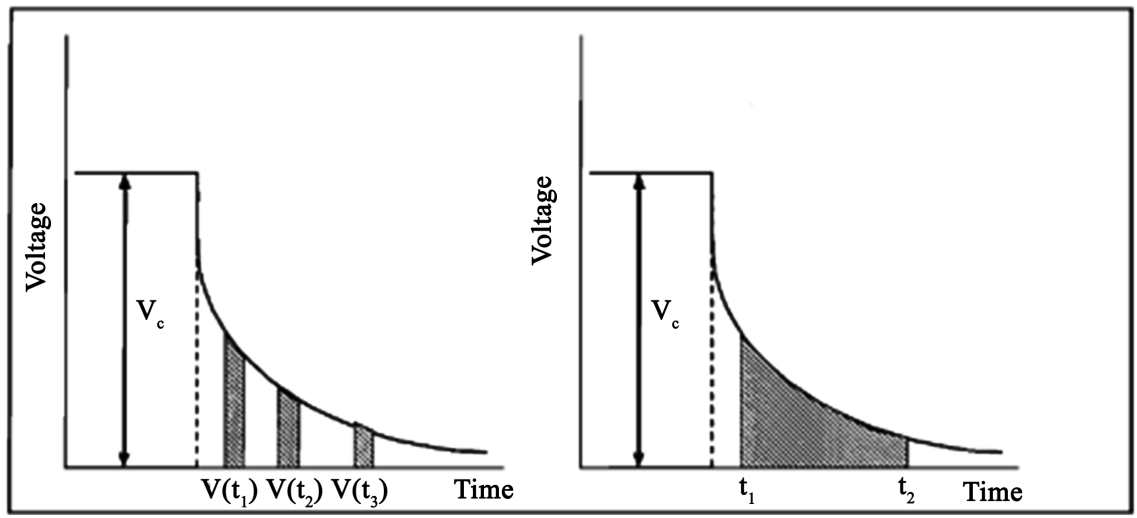

Figure 4. Time window chargeability.

are produced by switch-off the transmitted current and measure the potential decay. This is known as the apparent chargeability $(M)$. The most common measurement of the magnitude of the IP effect in the time domain is chargeability $M$.

The common chargeability expression is:

$$
M_{a}=\frac{1}{V_{p}} \int_{t_{1}}^{t_{2}} V_{s}(t) \mathrm{d} t
$$

where $V_{p}$ is the primary voltage, $V_{s}$ represents secondary voltage, and $V_{t}$ is the voltage decay with a time interval between $t_{1}$ and $t_{2}$. Units of chargeability are millivolts per volt $(\mathrm{mV} / \mathrm{V})$ or millisecond $(\mathrm{ms})$.

In the frequency domain, measurements involve measuring the resistivity at varying frequencies one higher than the other, transmitted one after the other. The IP effect is the percentage frequency effect (PFE) defined as:

$$
\mathrm{PFE}=\frac{\rho_{2}-\rho_{1}}{\rho_{1}} * 100
$$

where $\rho_{2}$ and $\rho_{1}$ represent apparent resistivity at high and low frequencies respectively. PFE has units of percent.

The IP effect is influenced by the effective resistivity of the host rock and, consequently, by the type of electrolyte, pore size, temperature etc. Though, the metal factor (MF) can remove this effect to some extent (Telford, Geldart, \& 
Sheriff, 1990b).

Metal Factor is defined as the amount of sulfide minerals contained in rocks, in which the amount depends on the value FE. Metal factor is formulated as follows:

$$
\mathrm{MF}=2 \pi * 10^{5} \frac{\rho_{2}-\rho_{1}}{\rho_{1}}
$$

1000 is an arbitrary factor chosen to give MF values appropriate values from 10 upwards, and MF has of mhos per foot.

The concept of metal factor arose early in the development of the IP method, because it was felt that low resistivity values would damp the value of PFE more than high resistivity values.

\subsection{Characteristics of Different Arrays Configurations Types}

Several conventional electrode arrays are used for resistivity and IP surveying. There is no "best" method that can match with all situations encountered in the fields (Daniels, 1977) but the choice depends on the aim of prospecting; the geological aspects of the subsurface, the availability of holes; and economics (Daniels, 1977; Bing \& Greenhalgh, 2000). Table 2 describes common arrays configuration depending on the measured potential by assuming that the earth's resistivity is homogeneous and isotropic.

Surface configuration: Surface geophysical methods present a low spatial resolution, which decreases with increasing depth of investigation. Moreover, this can hinder the exposure of small-scale features such as cavities or leachate plumes. The use of electrodes in boreholes and pole-dipole arrays are recommended to extend the adequate depth of investigation (White et al., 2001).

Hole-to-surface measurements are performed by setting a pole or dipole source down a borehole and making surface dipole measurements away from the source hole (Daniels, 1977).

Borehole: Vertical profiles can detect both in-hole and off-hole features, but the enlargement depends on the configuration (Palich \& Qian, 2007).

Single-hole arrays (Vertical Resistivity Profiling (VRP)) use a pole or bipole source and potential receiver in the same borehole (Daniels, 1977).

Hole-to-hole measurements (Borehole Resistivity Tomography (BRT)), this is performed by installing a pole or a dipole current source in a borehole and placing a pole or a dipole potential-receiver nearby borehole (Daniels, 1977).

The cross-borehole resistivity measurements seem to be more useful than single-borehole measurements (Yang \& Ward, 1985; Wright \& Ward, 1987; Qian, Milkereit, \& Gräber, 2007; Ali et al., 2020). Qian, Milkereit, and Gräber (2007) reported the success of the cross-borehole method, where the imaging of the massive sulfide mineralization was more extended compared to the single borehole. However, the cross-borehole anomalies are smaller by using a pole-pole array than the dipole-dipole array. Though, with the cross-borehole mise-àla-masse method, the anomalies are more significant than other cross borehole methods (Wright \& Ward, 1987). 
Table 2. The common electrode arrays.

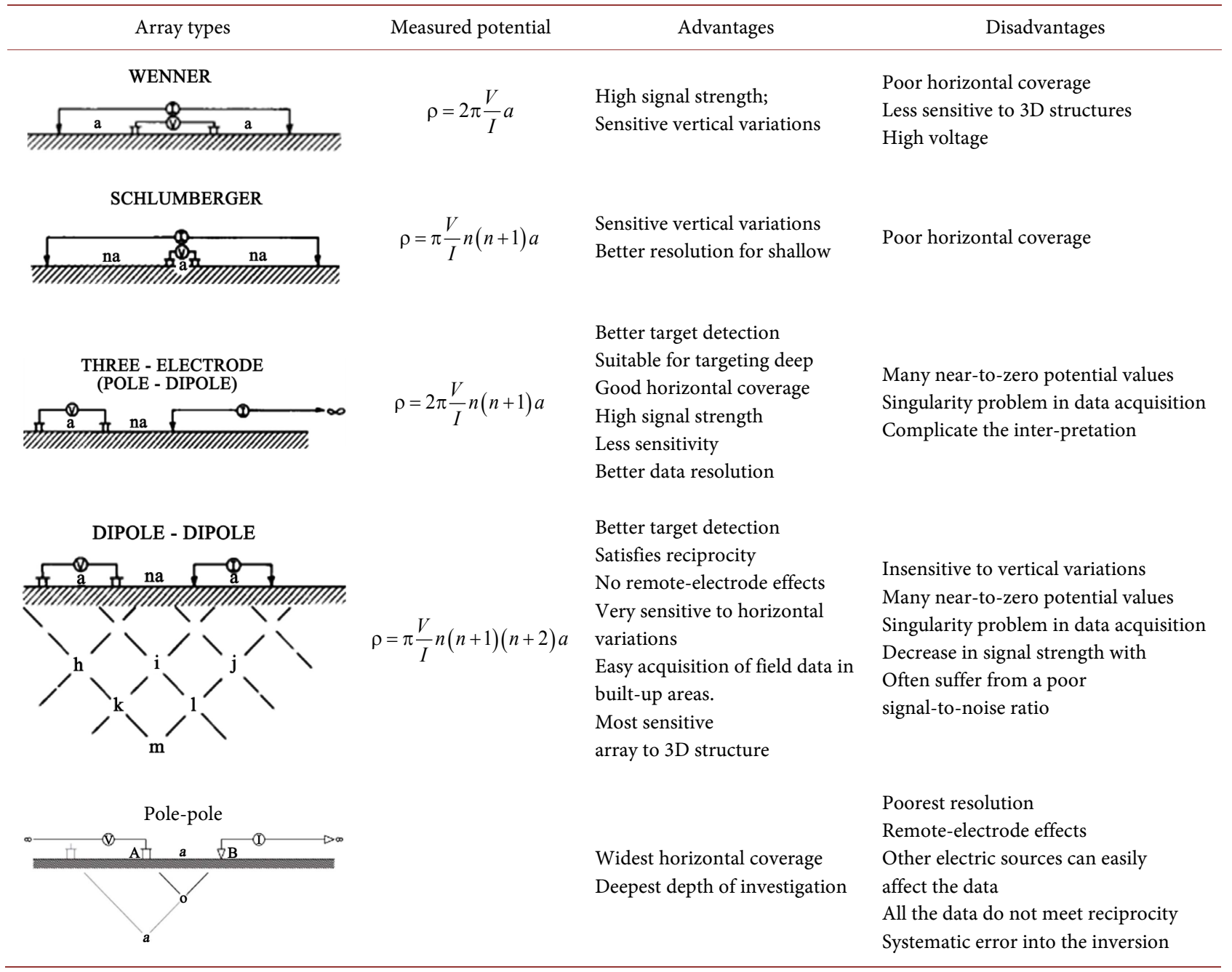

(Edwards, 1977; Telford, Geldart, \& Sheriff, 1990b; Furman \& Ferre, 2003; Aizebeokhai, 2010; Tavakoli et al., 2016a; Hassan, Rai, \& Anekwe, 2017).

For shallow targets hole- to-surface measurements may locate the target with a minimal field effort (Daniels \& Scott, 1981; Daniels, 1983; Tsourlos et al., 2011). In the case of borehole-to-surface, Pole-dipole and dipole-dipole configurations are preferred because other arrays such as Wenner, Wenner-Schlumberger, and Gradient Schlumberger are more prone to artifact distortion (White et al., 2001; Tsourlos et al., 2011). The lateral position of the target can easily set by hole-to-surface or conventional dipole-dipole surface arrays (Daniels \& Scott, 1981). Ideally, the horizontal position of the body can be established by a conventional surface survey or a hole-to-surface survey while the vertical position of the body can be determined by hole-to-hole or single-hole measurement (Daniels \& Scott, 1981). For the intersection of mineralization and drill holes, mise-á-la-masse surveys appear more promising for imaging the minerals' orientation and strike extent (Tyne, 1980; Guo, Dentith, \& Zhao, 2000). However, for near-surface with borehole resistivity surveys, accurate array locations and correct geometry factors are very important to account for bo- 
rehole deviation effect and for accurate imaging (Guo, Milkreit, \& Qian, 2014). For all, shorter electrode intervals are needed to better define shallow anomalies and mineralized veins (Mammo, 2013).

\section{1D, 2D, and 3D Imaging Surveys and Inversion Processes}

\subsection{D, 2D, and 3D Dimensional Surveys}

The Electrical Resistivity and IP methods can provide 1D, 2D or 3D images of their distribution in the subsoil.

\subsubsection{D Dimensional Surveys}

Since the early 1920 s to the late 1980s, the resistivity method's first commercial use was one-dimensional (1-D) mapping method for the profiling and sounding methods (Ghosh, 1971; Ward, 1990; Meheni et al., 1996; Loke, 2011; Sharma \& Verma, 2015). The method is quick and simple in application (Ghosh, 1971; Ogunbo, 2018), it has been widely used to investigate the ground for resource management, such as mineral, petroleum, and groundwater resources (Loke, 2011). With this survey, the subsurface should consist of horizontal layers (Loke, 2011; Loke et al., 2013). In homogeneous, 1-D survey provides good results (Karim, 2015). However, 1-D survey does not provide significant lateral changes, which may bring to gives inaccurate results or misleading results (Loke, 2011; Loke et al., 2013).

\subsubsection{D Dimensional Surveys}

2-D imaging surveys are mostly used in mineral exploration. Two-dimensional multi-electrode arrays produce simultaneous and display both horizontal and vertical variations in resistivity (Loke, 2011; Loke et al., 2013). Wenner, Wenner-Schlumberger, dipole-dipole, pole-pole or pole-dipole arrays are the most common use, depending on the respective position of the potential electrodes and the current electrodes.

The sensitivity to horizontal and vertical heterogeneities, depth of investigation, data coverage and signal strength change depends on type of configurations array and the background noise level (Samouëlian et al., 2005). Commonly 2-D inversion for resistivity data was used by many of the reviewed papers (White et al., 2001; Moreira et al., 2012; Goto et al., 2013; Mammo, 2013; Côrtes et al., 2016; Tavakoli et al., 2016b). Figure 5 clearly shows the correlation of Resistivity and IP and their efficiency in $2 \mathrm{D}$ prospecting.

Figure 5 indicates that both resistivity and IP show a large contrast between the electrical properties of sulfide and their host rocks. The 2-D and 3-D forward interpretations are based on finite-difference, finite-element, transmission surface, integral-equation, or hybrid finite-element/integral equation formulation to provide a reasonable estimate of the subsurface structure (Zonge et al., 2014).

\subsubsection{D Dimensional Surveys}

3D modeling is now playing an important role in very complex exploration 

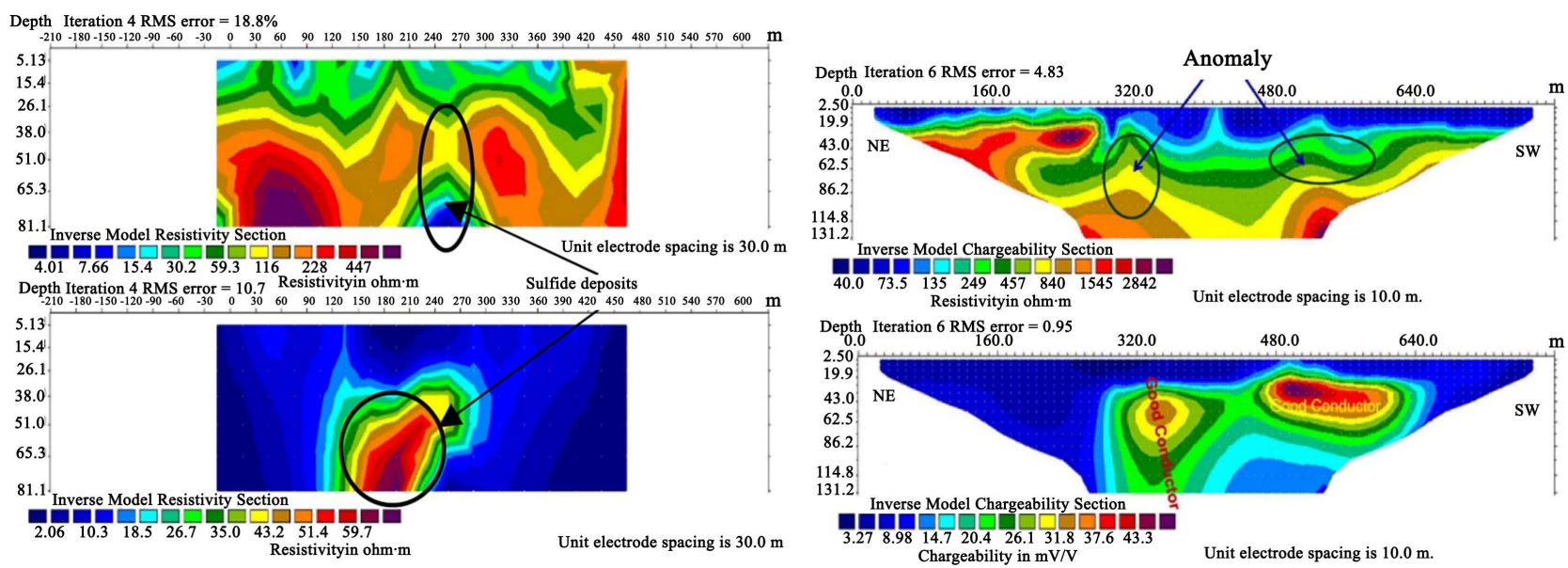

Figure 5. Correlation of low resistivity and high chargeability in sulfide (Ja, Oo, \& Arce, 2014; Kumar et al., 2016; Tavakoli et al., 2016b).

(Loke et al., 2013; Sharma \& Verma, 2015). Three-dimensional electrical resistivity can be obtained by reconstructing a two-dimensional network of parallel pseudo-sections or using a square array of four electrodes (Bentley \& Gharibi, 2004). Several studies show the effectiveness of the 3D survey compared to $1 \mathrm{D}$ and $2 \mathrm{D}$. The $3 \mathrm{D}$ surveys perform well with high accuracy in short time (Bentley \& Gharibi, 2004). When the dipole-dipole or pole-dipole electrode array is more affected by spatial effects, 3D inversion can control the validity of the pseudo-3D approach (Orfanos \& Apostolopoulos, 2011). 3D surveys are useful in the creation of the amplitude and geometry of the complex resistivity anomalies (Bentley \& Gharibi, 2004; Milkereit et al., 2008; Orfanos \& Apostolopoulos, 2011; Mammo, 2013; Tavakoli et al., 2016a). Thus, the method can give correct position and the improved delineation of the target (White et al., 2001; Orfanos \& Apostolopoulos, 2011; Moreira et al., 2012; Côrtes et al., 2016; Tavakoli et al., 2016b). Figure 6 and Figure 7 hold examples that show the effectiveness of 3D in sulfide explorations. 3Dinversion survey techniques provide high data acquisition rates, increase target resolution, offer a greater depth of penetration, and hence very cost-effective (White et al., 2001; Moreira et al., 2012; Côrtes et al., 2016; Tavakoli et al., 2016b).

The above images mainly contributed to better understanding the distribution of the sulfide mineralization around the mineralization zone. For example in Tavakoli et al.'s study, 3Dresistivity/IP was capable of providing a comprehensive overview of the electrical distribution in the upper $\sim 450 \mathrm{~m}$ of the crust, which is of great importance for targeting VMS ore (Tavakoli et al., 2016b).

3D inversion is suitable for detecting electrical anisotropy while $1 \mathrm{D}$ and $2 \mathrm{D}$ were less pronounced (Meheni et al., 1996; Sretenovic \& Arnaut, 2019). But, many facts need to be considered before choosing the method such as subsurface heterogeneity, background noise level, characteristics of an array, etc. Thus, multiple configurations are suggested to improve the reading of different subsoil features (Hesse, Jolivet, \& Tabbagh, 1986; Côrtes et al., 2016). 


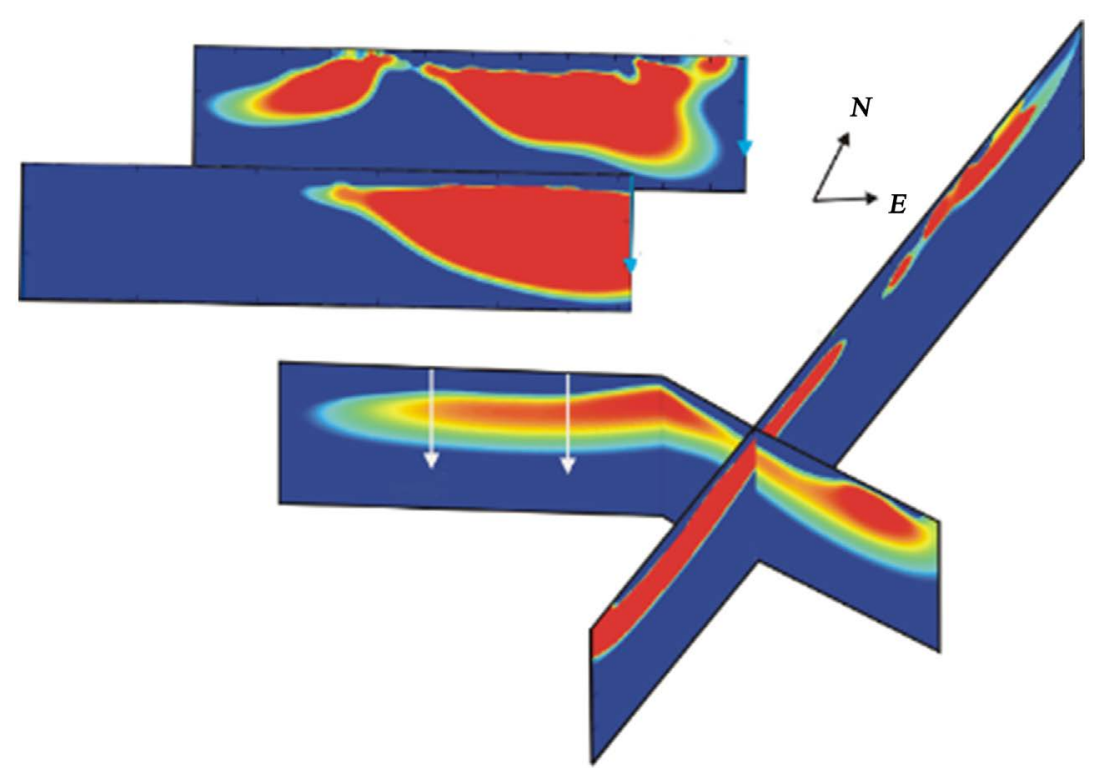

Figure 6. Perspective view of 3D resistivity inversion (Milkereit et al., 2008).

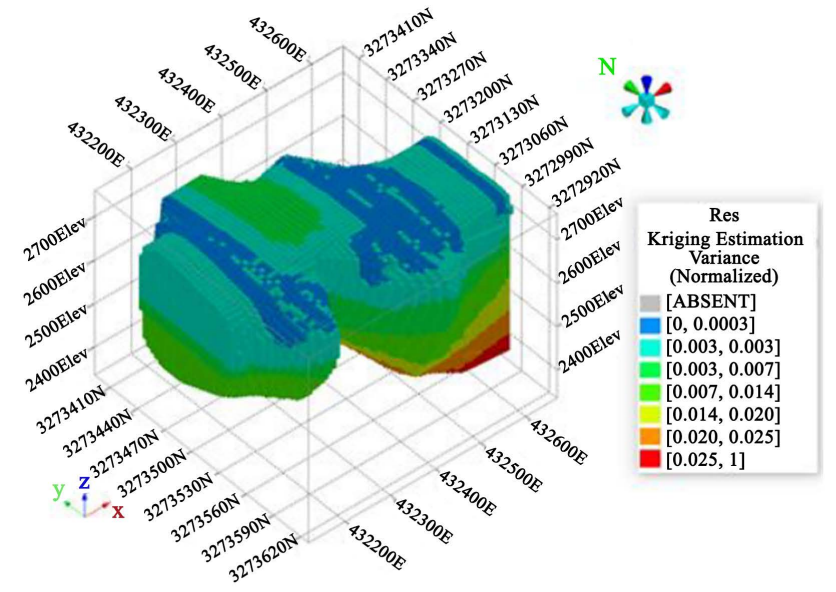

(a)

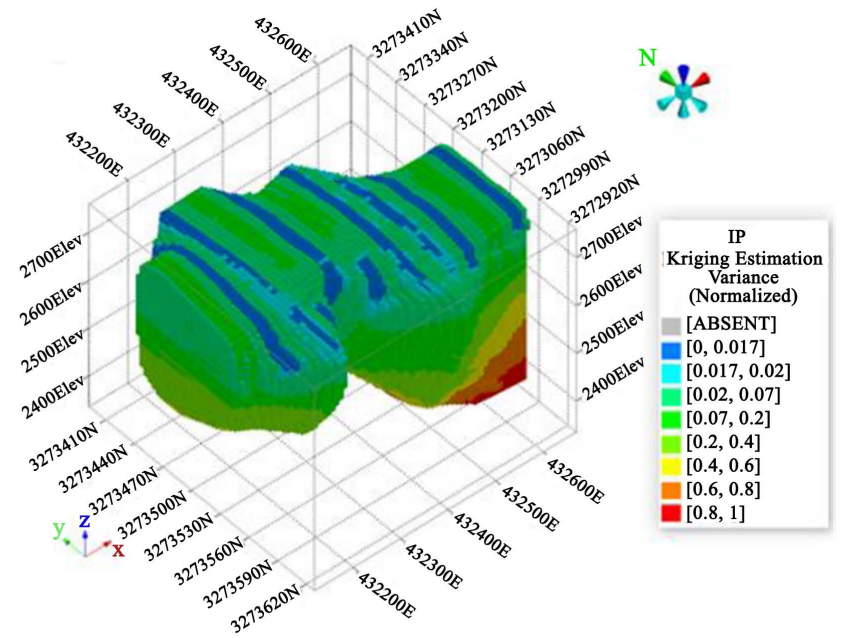

(b)

Figure 7. 3D visualization of the electrical resistivity (a); chargeability (b) (Babaei et al., 2020).

\subsection{Inversion Process for Sulfide Investigation}

To obtain an accurate picture of the subsurface, it is necessary to carry out the pseudo section's inversion (Loke \& Barkert, 1995). The inversion is performed by forward modeling operator by calculating theoretical data from input data and thereby calculating derivatives of the data with regard to the parameter (Pelton, Rijo, \& Swift, 1978; Madsen et al., 2018). The massive sulfides deposits are indicated by the coincidence of high chargeability and low resistivity values after inversion (Moreira et al., 2012). It is noticeable that a suitable inversion method must simultaneously minimize the effects of data error and model parameter errors (Ja, Oo, \& Arce, 2014). Therefore, to produce a better inversion, there should be re-run adjusting default parameters by manual selection of set- 
tings such as vertical and horizontal weighting (Robertson \& Hart, 2013). The "least-squares method" is the most method used amongst the papers analyzed in this review. The "least-squares method" seems to be the method that can successfully remove the distortions in the apparent resistivity pseudo section because it separates the electrode array geometry's effect on the apparent resistivity values from that which results from the subsurface resistivity (Loke \& Barkert, 1995). It also separates overlapping anomalies caused by different bodies (Loke \& Barkert, 1995).

\section{Interpretation of Electrical Resistivity and IP Variation for Sulfide Ores and Their Host Rocks}

\subsection{Electrical Properties of Sulfide Host Rocks}

The effectiveness of detecting sulfide deposits depends on the evolution of their hosting with adequate contrast in their physical properties between the base metals and their host rocks. Resistivity appears to be negatively correlated with porosity, Basalts indicate high resistivity and low IP along the resistivity, volcanic tuff areas are predominated by high resistivity values (Tavakoli et al., 2016b; Komori et al., 2017; Evrard et al., 2018) etc. The resistivity variation of various host rocks and sulfide minerals is summarized in Table 3 .

Sulfide in a sedimentary host may be derived directly from the mantle or by reduction of sulfate either by a chemical or biological mechanism (Trudinger, 1981). Resistivity and chargeability of sulfide mineralization in sedimentary host

Table 3. Electrical resistivities range sulfide minerals and host rocks.

\begin{tabular}{|c|c|c|c|c|c|c|c|c|c|}
\hline & & $10^{-2}$ & $10^{-1}$ & $10^{\circ}$ & $10^{1}$ & $10^{2}$ & $10^{3}$ & $10^{4}$ & $10^{5}$ \\
\hline & & \multicolumn{8}{|c|}{$\operatorname{Resistivity~}(\Omega \cdot \mathrm{m})$} \\
\hline \multirow{3}{*}{$\begin{array}{l}\text { Unconsolidated } \\
\text { sediments }\end{array}$} & Soil & & & & & & & & \\
\hline & Clay & & & & & & & & \\
\hline & Sands and gravel & & & & & & & & \\
\hline \multirow{3}{*}{$\begin{array}{l}\text { Sedimentary } \\
\text { rocks }\end{array}$} & Shale & & & & & & & & \\
\hline & Sandstone & & & & & & & & \\
\hline & Limestone & & & & & & & & \\
\hline \multirow{4}{*}{$\begin{array}{c}\text { Ignous } \\
\text { metamorphic } \\
\text { rocks }\end{array}$} & Granite & & & & & & & & \\
\hline & Altered granite & & & & & & & & \\
\hline & Basalt & & & & & & & & \\
\hline & Graphytic Schist & & & & & & & & \\
\hline \multirow{4}{*}{$\begin{array}{l}\text { Base metal } \\
\text { sulfides }\end{array}$} & Pyrite & & & & & & & & \\
\hline & Pyrrhotite & & & & & & & & \\
\hline & Galena & & & & & & & & \\
\hline & Chalchopyrite & & & & & & & & \\
\hline
\end{tabular}

(Ward, 1988; Telford, Geldart, \& Sheriff, 1990b; Cardimona, 2002; Idornigie, Olorunfemi, \& Omitogun, 2006). 
expects to much contrast and detectable (Meju, 2002; Airo, 2015), because of their resistivity variations: Shale and clays present low values followed by sandstones with intermediate values, while coal and limestone beds have high values (Lau, 2000). Generally, sulfide in sedimentary hosts indicates low resistivity values with a strong correlation between the low resistivity and high chargeability areas for most of sedimentary host (Côrtes et al., 2016; Evrard et al., 2018). Massive sulfide surveyed around the submarine area usually shows low resistivity values lower than the seawater value (Goto et al., 2013; Komori et al., 2017; Ishizu et al., 2019). But, the sulfide hosted by quartz and carbonates leads to act as good electrical insulators with higher resistivity values (Katsube et al., 2003; Moreira et al., 2014; Côrtes et al., 2016; Han et al., 2016; Ishizu et al., 2019).

Seafloor massive sulfide (SMS) deposits are considered a high potential source of economic minerals s such as zinc, copper, tin, gold, and silver (Emsbo, 2007; Haroon et al., 2018). The electrical resistivity methods have revealed that SMS deposits exhibit a strong IP effect and lower resistivity than the surrounding host rock (Iijima \& Sayanagi, 2013; Hördt et al., 2016; Ishizu et al., 2019). SMS area deposit indicates low resistivity values similar to or lower than the seawater (Iijima \& Sayanagi, 2013).

Volcanogenic Massive Sulfide (VMS) deposits appear to have been formed by concentrations of base metal mineralizations by which their host rocks are dominated by submarine volcanic (Doyle \& Allen, 2003; Iijima \& Sayanagi, 2013; Ishizu et al., 2019). Most VMS deposits are classified based on metal content, tectonic context, or age (Barrie \& Hannington, 1999; Doyle \& Allen, 2003; Iijima \& Sayanagi, 2013; Ishizu et al., 2019). VMS deposit may be characterized by a distinct zonation of the ore, gangue, and hydrothermally altered minerals. But, compared to sedimentary rock, igneous and metamorphic rocks present very high resistivity values (Lau, 2000; Airo, 2015). In the Iberian Pyrite belt, in Bathurst districts in Canada and Kuroko province of Japan, sulfide observed as volcano-sedimentary stratigraphic layers for being closely associated with volcanic lavas and pyroclastic rocks. They have formed a different relative participation of sedimentary/bacterio-genic and hydrothermal processes (Boulter, 1996; Barrie \& Hannington, 1999; Sáez et al., 1999; Lentz \& McCutcheon, 2006; Lentz, Thorne, \& Beal, 2009; Walker, 2010; Piercey, Peter, \& Herrington, 2015; Almod et al., 2019). VMS deposits (Sulfide in mafic or felsic hosted or occur as intercalation of basalts) are characterized by high electrical conductivity, high chargeability bordering zones, and sediments (such as graphitic shales) are more conductive than the associated volcanic host (Tavakoli et al., 2016b). However, the geochemical processes of weathering such as humidity, porosity, and hydrothermal alteration form clay can affect the target's resistivity. Also, major faults, fracture zones, and related structural control features in VMS prospects may be saturated with saline fluids, making them electrically conductive (Meju, 2002; Moreira et al., 2014; Tavakoli et al., 2016b). Though, when mineralized, they will be recognized by their elevated chargeability (Hawke \& Brooker, 2001). 


\subsection{Electrical Resistivity and Chargeability of Sulfide Ores}

Common sulfides except sphalerite, have high electrical conductivities (Wells, 1914; Ross, 1957; Meju, 2002; Pearce, Pattrick, \& Vaughan, 2006; Aradis, Annigan, \& Ewing, 2007; Airo, 2015) Resistivity and IP of Sulfide deposits depend very strongly on their quantity and the degree of connection between the various mineral grains or veins in the relevant host rock. When sulfide grains are isolated, they are not good electrical conductors because conductivity increases with the concentration of metallic particles (Revil, Florsch, \& Mao, 2015). The ore bodies constituting more than $80 \%$ sulfide are considered as having "massive" texture; it is clear they are good electrical conductors (Langore et al., 1989). $20 \%$ up to $80 \%$ of the total volume is considered as "veinlet" texture. Due to electrical connections between the veinlets, such sulfide are also good electrical conductors (Langore et al., 1989). Sulfide content in the disseminated ore is $10 \%$ - 20\% (Langore et al., 1989), because of the disseminated texture, sulfide is not good electrical conductors. It is also noted that the chargeability increase depending on the volumetric content of metallic particles (Scott \& West, 1969; Revil, Florsch, \& Mao, 2015).

The Pyrite and galena are frequently available as reasonably large single crystals. Simultaneously, chalcopyrite, pyrrhotite, and arsenopyrite occur in a compact, microcrystalline forms (Parasnis, 1956) massive sulfide vary in thickness from 2 to $10 \mathrm{~cm}$, massive chalcopyrite layers vary in thickness from 2 to $5 \mathrm{~mm}$ (Tivey et al., 1995). Pyrrhotite laths are 20 to $30 \mu \mathrm{m}$ long, and $3 \mu \mathrm{m}$ wide and occur in interstices and intergrown with outer edges of chalcopyrite grain. Forty to $100 \mu \mathrm{m}$ clusters of sphalerite are intergrown with minor amounts of Pyrite $(<10 \mu \mathrm{m})$ (Tivey et al., 1995).

Pyrrhotite is highly conducive and can significantly influence a sulfide body's general electrical conductivity signature (Roach \& Fitzpatrick, 2003). Pyrite and chalcopyrite also give potentials higher polarized (too conductive) state than galena (Wells, 1914; Roach \& Fitzpatrick, 2003), but sphalerite is generally insultator with less conductivity and lower IP signatures than other sulfide minerals (Komori et al., 2017; Evrard et al., 2018). It can be conducive when associated with other conducive/chargeable sulfide minerals such as pyrite and pyrrhotite, even in small quantities (Roach \& Fitzpatrick, 2003; Evrard et al., 2018). Even though (Hawke \& Brooker, 2001)'s research showed that sphalerite is the primary mineral source of the induced polarisation effect observed in their investigated samples (Hawke \& Brooker, 2001). It is also noted that Cu-bearing ores are likely to be more conductive than sphalerite-rich $\mathrm{Zn}$ ores (Airo, 2015). Chalcopyrite is highly conductive but usually constitutes only a small part of the total sulfide volume in many deposits. Table 4 clearly describes the conductivities and chargeability of major sulfide minerals.

As mentioned in Table 4, the geophysical responses of massive sulfide usually dominated by low resistivity and high chargeability. It is not easy to make any conclusive deduction about exact resistivity and IP values for each type of sulfide. 
Table 4. Resistivity and chargeability of common sulfide minerals.

\begin{tabular}{cccc}
\hline \multirow{2}{*}{ Minerals } & \multicolumn{2}{c}{ Resistivity } & IP \\
\cline { 2 - 4 } & $3 \times 10^{-5}-1.5$ & $\Omega \cdot \mathrm{m}$ & $\mathrm{ms}$ \\
\hline Pyrite & $1.2 \times 10^{-5}-0.3$ & $0.005-5$ & 13.4 \\
Chalcopyrite & $3 \times 10^{-5}-300$ & $0.003-0.03$ & 9.4 \\
Galena & $3.8 \times 10^{11}$ & & 3.7 \\
Sphalerite & - & $0.001-0.005$ & - \\
Pyrrhotite & - & 0.03 & - \\
Arsenopyrite & $10-50$ & & \\
Sulfides ore & & & \\
\hline
\end{tabular}

(Parasnis, 1956; Telford, Geldart, \& Sheriff, 1990b; Pearce, Pattrick, \& Vaughan, 2006; Airo, 2015; Evrard et al., 2018).

Different geological settings of the areas, make identical minerals to have different geophysical signatures or different minerals to produce the identical geophysical signature (Langore, Alikaj, \& Gjovreku, 1989; Moreira et al., 2014; Côrtes et al., 2016). Some of the reviewed papers did not found differences between various sulfides, i.e., pyrite and chalcopyrite, in the spectral IP parameters with laboratory analysis (Langore, Alikaj, \& Gjovreku, 1989). Also, mineralization may be of a chargeable nature because of the presence of other minerals which strongly associated with them like pyrite/marcasite (Côrtes et al., 2016; Evrard et al., 2018). Thus, minerals with high metallic conductivity even for disseminated sulfide ores, can have strong IP effects (Wang \& Strangwayt, 1981). Though, the presence of graphite-bearing limestone, IP surveys is less useful for mapping sulfide mineralization (Guo, Dentith, \& Zhao, 2000). But, graphite rarely occurs in massive sulfide. Table 5 presents examples of resistivity and IP methods in the exploration of sulfide deposits. It describes the types of surveys used, types of minerals and types of host rocks encountered, and shows their resistivity and IP responses.

\section{Factors Affecting Exploration of Sulfides}

Here are some factors that affect exploration of sulfide:

$\checkmark$ The exploration of sulfides is potential sources of pollution, of the air and of surface waters and soils (Vaughan \& Corkhill, 2017).

$\checkmark$ The 1-D survey does not provide significant lateral changes, which may bring to gives inaccurate results or misleading results.

$\checkmark$ When using 2D, the geological structures do not change in the direction perpendicular to the survey line, creating errors in interpretation.

$\checkmark$ To delete negative IP data may cause the loss of essential information (Dahlin \& Loke, 2015).

$\checkmark$ Using large electrode spacing can mask data of thin layers (Mammo, 2013; Tavakoli et al., 2016b). 
Table 5. Examples of resistivity and IP methods in the exploration of sulfide deposits.

\begin{tabular}{|c|c|c|c|c|c|c|c|c|}
\hline Date & Location & $\begin{array}{l}\text { Types of } \\
\text { mineral }\end{array}$ & Depth & Thick & $\begin{array}{l}\text { Host } \\
\text { rocks }\end{array}$ & $\begin{array}{l}\text { Resistivity } \\
\text { responses }\end{array}$ & $\begin{array}{l}\text { Chargeability } \\
\text { and IP effect } \\
\text { of minerals }\end{array}$ & $\begin{array}{l}\text { Dimensional } \\
\text { survey }\end{array}$ \\
\hline 1981 & Australia & pyrite & $7 \mathrm{~m}$ & 8 to $9 \mathrm{~m}$ & Volcanic rocks & & $30 \mathrm{~ms}, 4 \%$ & \\
\hline 1983 & $\begin{array}{l}\text { United } \\
\text { state }\end{array}$ & $\begin{array}{l}\text { Porphyry } \\
\text { copper }\end{array}$ & & & Sedimentary & $\begin{array}{l}\sim 75 \Omega \cdot \mathrm{m} \\
\text { Laboratory }\end{array}$ & $6 \%$ & \\
\hline 1989 & Albania & $\begin{array}{c}\text { sulfide } \\
\text { Massive } \\
\text { and } \\
\text { disseminated }\end{array}$ & - & $40-250$ & sediments & $30-80 \Omega \cdot \mathrm{m}$ & $15 \mathrm{mV} / \mathrm{V}$ & $1 \mathrm{D}$ \\
\hline 1995 & Albania & $\begin{array}{l}\text { pyrite and } \\
\text { chalcopyrite } \\
\text { Massive and } \\
\text { disseminated }\end{array}$ & & & $\begin{array}{l}\text { volcano-sedimentary } \\
\text { rocks }\end{array}$ & $<50 \Omega \cdot \mathrm{m}$ & $>20$ & $2 \mathrm{D}$ \\
\hline 1997 & Turkey & $\begin{array}{c}\text { chalcopyrite-pyrite- } \\
\text { sphalerite } \\
\text { Disseminated }\end{array}$ & & & volcanic rock & $\begin{array}{l}0.6 \text { to } 2 \Omega \cdot \mathrm{m} \\
\sim 10 \Omega \cdot \mathrm{m} \\
\text { Laboratory }\end{array}$ & & $2 \mathrm{D}$ \\
\hline 2000 & China & $\begin{array}{l}\text { pyrite, sphalerite } \\
\text { and galena }\end{array}$ & & & $\begin{array}{l}\text { schist and } \\
\text { limestone }\end{array}$ & $\begin{array}{c}300-500 \Omega \cdot \mathrm{m} \\
\text { Laboratory }\end{array}$ & $\geq 12 \%$ & $1 \mathrm{D}$ \\
\hline 2001 & Australia. & $\begin{array}{l}\text { sphalerite, pyrite } \\
\text { and galena }\end{array}$ & & & $\begin{array}{c}\text { The sediment } \\
\text { hosted }\end{array}$ & $\begin{array}{l}16.8-760.8 \\
\text { Laboratory }\end{array}$ & $10-25 \mathrm{msec}$ & \\
\hline 2003 & Australia & $\begin{array}{c}\text { pyrite-chalcopyrite } \\
\text { sphalerite, } \\
\text { Massive }\end{array}$ & & & $\begin{array}{l}\text { Volcanic } \\
\text { Hosted }\end{array}$ & $\begin{array}{l}0.0002-0.8 \Omega \cdot \mathrm{m} \\
\quad \text { Laboratory }\end{array}$ & - & $2 \mathrm{D}$ \\
\hline 2007 & Canada & $\mathrm{Zn}-\mathrm{Pb}-\mathrm{Ag}$ deposit & $82 \mathrm{~m}$ & $<40 \mathrm{~m}$ & $\begin{array}{l}\text { Volcanic and } \\
\text { sedimentary } \\
\text { hosted }\end{array}$ & $<40 \Omega \cdot \mathrm{m}$ & & $2 \mathrm{D}$ \\
\hline 2008 & $\begin{array}{l}\text { Nigeria } \\
\text { Benue } \\
\text { state }\end{array}$ & $\begin{array}{l}\text { galena, sphalerite } \\
\text { and pyrite }\end{array}$ & $50 \mathrm{~m}$ & & $\begin{array}{l}\text { Sedimentary } \\
\text { rocks }\end{array}$ & $100-300 \Omega \cdot \mathrm{m}$ & $\begin{array}{c}20-90 \\
3-6 \text { PFE }\end{array}$ & $2 \mathrm{D}$. \\
\hline 2013 & Japan & $\begin{array}{l}\text { Submarine massive } \\
\text { sulfide (SMS) }\end{array}$ & & & $\begin{array}{l}\text { Hydrothermal } \\
\text { chimneys. }\end{array}$ & $\leq 0.3 \Omega \cdot \mathrm{m}$ & & $2 \mathrm{D}$ \\
\hline 2012 & BLAZIL & $\begin{array}{l}\text { Oxides and } \\
\text { sulfide }\end{array}$ & & & $\begin{array}{l}\text { quartz, clay } \\
\text { and schists }\end{array}$ & $<20 \Omega \cdot \mathrm{m}$ & $>30 \mathrm{~ms}$ & \\
\hline 2013 & Ethiopia & $\begin{array}{l}\text { chalcopyrite, } \\
\text { sphalerite, pyrite, } \\
\text { pyrrhotite }\end{array}$ & & & $\begin{array}{l}\text { Volcanic } \\
\text { hosted }\end{array}$ & $<500$ & $>40 \mathrm{~ms}$ & $2 \mathrm{D} \& 3 \mathrm{D}$ \\
\hline 2016 & BLAZIL & $\begin{array}{l}\text { copper-porphyry } \\
\text { Cu disseminated }\end{array}$ & $\begin{array}{c}\text { below } \\
50 \mathrm{~m}-80 \mathrm{~m}\end{array}$ & & $\begin{array}{c}\text { In } \\
\text { sediments }\end{array}$ & $\begin{array}{l}\text { Less than } \\
20 \Omega \cdot \mathrm{m}\end{array}$ & & $2 \mathrm{D}$ \\
\hline 2014 & Nigeria & $\begin{array}{l}\text { galena, sphalerite } \\
\text { and pyrite }\end{array}$ & $50 \mathrm{~m}$ & $30 \mathrm{~m}$ & $\begin{array}{l}\text { barite and } \\
\text { gypsum }\end{array}$ & $100-300 \Omega \cdot \mathrm{m}$ & & $2 \mathrm{D}$ \\
\hline 2016 & sweden & $\begin{array}{l}\text { pyrite, sphalerite, } \\
\text { chalcopyrite, } \\
\text { and arsenopyrite }\end{array}$ & $\begin{array}{l}\approx 1-\mathrm{km} \\
\text { depth }\end{array}$ & & $\begin{array}{l}\text { metasedimentary } \\
\text { rocks and } \\
\text { volcanic rocks }\end{array}$ & $\begin{array}{c}\text { Depends on } \\
\text { the site } \\
2 \mathrm{k} \Omega \cdot \mathrm{m}-4 \mathrm{k} \Omega \cdot \mathrm{m} ; \\
6 \mathrm{k} \Omega \cdot \mathrm{m}-10 \mathrm{k} \Omega \cdot \mathrm{m}\end{array}$ & $\begin{array}{l}\leq 27 \mathrm{mV} / \mathrm{V} \\
-70 \mathrm{mV} / \mathrm{V}\end{array}$ & $2 \& 3 \mathrm{D}$ \\
\hline
\end{tabular}




\section{Continued}

\begin{tabular}{|c|c|c|c|c|c|c|c|c|}
\hline 2016 & $\begin{array}{l}\text { South } \\
\text { Korea }\end{array}$ & $\mathrm{Au}-\mathrm{Ag}$ deposits & & & $\begin{array}{l}\text { the solidification } \\
\text { (quartz veins) } \\
\text { exposed in outcrop }\end{array}$ & $<600 \Omega \cdot \mathrm{m}$ & $\begin{array}{l}>2.7 \mathrm{mV} \cdot \mathrm{V}^{-1} \\
-3 \mathrm{mV} \cdot \mathrm{V}^{-1}\end{array}$ & $2 \mathrm{D} \& 3 \mathrm{D}$ \\
\hline 2016 & Indian & $\begin{array}{l}\mathrm{Ni}-\mathrm{Cu}-\mathrm{PGE} \text { ores } \\
\text { and base metal } \\
\text { sulfide deposits } \\
\text { (chalcocite, } \\
\text { chalcopyrite or } \\
\text { pyrite minerals) }\end{array}$ & $\begin{array}{c}-55 \mathrm{~m} \\
\text { to } 74 \mathrm{~m} \\
-320 \mathrm{~m} \\
\text { and } 480 \mathrm{~m} \\
-55 \mathrm{~m} \text { to } \\
74 \mathrm{~m}\end{array}$ & & mafic-ultramafic & $\begin{array}{l}\text { 1) } 200-1500 \Omega \cdot \mathrm{m} \\
\text { 2) } 1500-11,000 \Omega \cdot \mathrm{m} \\
\text { 3) } 1580-10,000 \Omega \cdot \mathrm{m}\end{array}$ & $\begin{array}{l}\text { Depends on } \\
\text { the site but } \\
\text { the lowest: } \\
\sim 20 \mathrm{mV} / \mathrm{V} \\
\text { Highest } \\
54 \mathrm{mV} / \mathrm{V}\end{array}$ & $2 \mathrm{D}$ \\
\hline 2016 & Iran & $\begin{array}{l}\text { pyrite, sphalerite, } \\
\text { and galena }\end{array}$ & - & - & - & $<200 \Omega \cdot \mathrm{m}$ & $\geq 30 \mathrm{~ms}$ & $2 \mathrm{D}$ \\
\hline 2018 & $\begin{array}{c}\text { South } \\
\text { Sulawesi }\end{array}$ & pyrite & & & $\begin{array}{l}\text { Sedimentary } \\
\text { host }\end{array}$ & $\leq 50 \Omega \cdot \mathrm{m}$ & $\geq 3 \%$ & $2 \mathrm{D} \& 3 \mathrm{D}$ \\
\hline 2018 & Belgium & $\begin{array}{c}\mathrm{Pb}-\mathrm{Zn} \text { (sphalerite, } \\
\text { with galena and } \\
\text { pyrite) }\end{array}$ & & & $\begin{array}{l}\text { sedimentary } \\
\text { host rock }\end{array}$ & $<80 \Omega \cdot \mathrm{m}$ & $>0.1 \mathrm{mV} / \mathrm{V}$ & $2 \mathrm{D}$ \\
\hline 2019 & Japan & $\begin{array}{l}\text { Copper, lead, } \\
\text { and zinc }\end{array}$ & $40 \mathrm{~m}$ & & $\begin{array}{c}\text { seafloor } \\
\text { massive sulfi }\end{array}$ & $<0.2 \Omega \cdot \mathrm{m}$ & & $2 \mathrm{D}$ \\
\hline 2019 & Canada & $\begin{array}{c}\mathrm{Ni}-\mathrm{Cu}-\mathrm{PGE} \\
\text { deposit }\end{array}$ & $\begin{array}{l}\text { beneath } \\
\text { the } 45 \mathrm{~m}\end{array}$ & & $\begin{array}{l}\text { volcanic } \\
\text { rocks }\end{array}$ & & $>25 \mathrm{mV} / \mathrm{V}$ & \\
\hline 2020 & Iran & $\begin{array}{c}\text { disseminated } \\
\text { nature } \\
\text { Porphyry } \mathrm{Cu} \\
\text { Mineralization }\end{array}$ & & $80 \mathrm{~m}$ & $\begin{array}{l}\text { Volcanic } \\
\text { tuff }\end{array}$ & $500 \Omega \cdot \mathrm{m}$ & $50 \mathrm{~ms}$ & $2 \mathrm{D} \& 3 \mathrm{D}$ \\
\hline
\end{tabular}

$\checkmark$ Interference from grounded structures such as pipelines, power lines, and fences can distort the signals (Sternberg, 2002).

$\checkmark$ Sometimes pyrite in fine-grained sediments such as mudstones and shales may produce false anomalies (Sternberg, 2002).

$\checkmark$ In the interpretation of resistivity data, the author should emphasize the fact that there are other causes of low resistivity other than sulfides and explain how to constrain the interpretation to be unique to sulfides.

\section{Conclusion}

It is much known about resistivity and IP surveys in mineral exploration. These methods are simple, fast, cheap, and effective for sulfide mineral exploration. The reviewed papers showed that these methods have been successfully used in sulfide exploration whereby many results showed that low resistivity correlates with high chargeability and vice versa. This review is the wealth of resistivity and IP properties exhibited by sulfide minerals and their host. This review covered different distinct techniques of investigation to make the reader understand the procedures and appropriate methods that can be applied in mining exploration by showing the success and problems affecting exploration. This research could be useful as a guide for the future geophysical studies such as geophysics, mineralogy or in mineral exploration. However, many authors did not give the values 
attributed to each type of minerals but the range value. Some failed to include the area covered during their survey. It could be suggested therefore to present the area covered during the geophysical survey or give the number of traverse and line with their space interval from which interested readers can get the idea of the area covered for future research.

\section{Acknowledgements}

This research study is supported by Hohai University.

\section{Consent to Participate}

I solemnly declare that this manuscript is the collection of original research data and does not contain any copied contents from other sources. Proper citations of previous works were made and to the best of our knowledge.

\section{Consent for Publication}

This work, whether in the same or different form, has not been presented and will not be submitted to any journal. I am fully aware of the legal outcome of this statement from me. Therefore, the authors consent for this paper to be published by this journal after acceptance.

\section{Availability of Data and Material}

All the data and materials used are available.

\section{Authors' Contributions}

All the authors contributed significantly to writing this article. The authors read and approved the final manuscript.

\section{Conflicts of Interest}

The authors declare that there is no competition of financial interests or personal relationships that could have appeared to influence the work reported in this paper.

\section{References}

Airo, M. (2015). Geophysical Signatures of Deposits. Geological Survey of Finland, 58, 9-70.

Aizebeokhai, A. P. (2010). 2D and 3D Geoelectrical Resistivity Imaging: Theory and Field Design. Scientific Research and Essays, 5, 3592-3605.

Ali, M., Sun, S., Qian, W., Bohari, A. D., Claire, D., Faruwa, A. R., \& Zhang, Y. (2020). Borehole Resistivity and Induced Polarization Tomography at the Canadian Shield for Mineral Exploration in North-Western Sudbury. In E3S Web of Conferences (Vol. 168, p. 00002). EDP Sciences. https://doi.org/10.1051/e3sconf/202016800002

Almod, G. R. et al. (2019). Massive Sulfide Ores in the Iberian Pyrite Belt: Mineralogical and Textural Evolution. Minerals, 9, 653. https://doi.org/10.3390/min9110653

Aradis, S. U. P., Annigan, P. E. H., \& Ewing, K. E. D. (2007). Mississippi Valley-Type 
Lead-Zinc Deposits. Geological Association of Canada, 3, 185-203.

Babaei, M. et al. (2020). Geostatistical Modeling of Electrical Resistivity Tomography for Imaging Porphyry $\mathrm{Cu}$ Mineralization in Takht-e-Gonbad Deposit, Iran. Journal of Mining \& Environment, 11, 143-159.

Barrie, C. T., \& Hannington, M. D. (1999). Chap. 1. Classification of Volcanic-Associated Massive Sulfide Deposits Based on Host-Rock Composition. In C. T. Barrie, \& M. D. Hannington (Eds.), Volcanic-Associated Massive Sulfide Deposits: Processes and EXamples in Modern and Ancient Settings (8th ed.). Society of Economic Geologists.

Bentley, L. R., \& Gharibi, M. (2004). Two- and Three-Dimensional Electrical Resistivity Imaging at a Heterogeneous Remediation Site Case History Two- and Three-Dimensional Electrical Resistivity Imaging at a Heterogeneous Remediation Site. Geophysics, 69, 674-680. https://doi.org/10.1190/1.1759453

Bery, A. A., Saad, R., Mohamad, E. T., Jinmin, M., Azwin, I. N., Tan, N. M. A., \& Nordiana, M. (2012). Electrical Resistivity and Induced Polarization Data Correlation with Conductivity for Iron Ore Exploration. The Electronic Journal of Geotechnical Engineering, 17, 3223-3233.

Bing, Z., \& Greenhalgh, S. A. (2000). Cross-Hole Resistivity Tomography Using Different Electrode Configurations. Geophysical Prospecting, 48, 887-912.

https://doi.org/10.1046/j.1365-2478.2000.00220.x

Boulter, C. A. (1996). Extensional Tectonics and Magmatism as Drivers of Convection Leading to Iberian Pyrite Belt Massive Sulphide Deposits? Journal of the Geological Society, 153, 181-184. https://doi.org/10.1144/gsjgs.153.2.0181

Cardimona, S. (2002). Electrical Resistivity Techniques for Subsurface Investigation. Rolla, MO: Department of Geology and Geophysics, University of Missouri-Rolla.

Côrtes, A. R. P. et al. (2016). Geoelectrical Prospecting for a Copper-Sulfide Mineralization in the Camaquã Sedimentary Basin, Southern Brazil. Geofísica Internacional, 55, 165-174.

Dahlin, T., \& Loke, M. H. (2015). Negative Apparent Chargeability in Time-Domain Induced Polarisation Data. Journal of Applied Geophysics, 123, 322-332. https://doi.org/10.1016/j.jappgeo.2015.08.012

Dandi, H. (2014). Application of Magnetometery, Electrical Resistivity and Induced Polarization for Exploration of Polymetal Deposits, a Case Study: Halab Dandi, Zanjan, Iran. 2nd International Conference on Advances in Engineering Sciences and Applied Mathematics, Istanbul, 4-7.

Daniels, J. J. (1977). Three-Dimensional Resistivity and Induced Polarization Modeling Using Buried Electrodes. Geophysical Prospecting, 42, 1006-1019. https://doi.org/10.1190/1.1440761

Daniels, J. J. (1983). Hole-to-Surface Resistivity Measurements. Geophysics, 48, 87-97. https://doi.org/10.1190/1.1441410

Daniels, J. J., \& Scott, J. H. (1981). Interpretation of Hole-to-Surface Resistivity Measurements at Yucca Mountain, Nevada Test Site. Report, U.S. Geological Survey. https://doi.org/10.3133/ofr811336

Doyle, M. G., \& Allen, R. L. (2003). Subsea-Floor Replacement in Volcanic-Hosted Massive Sulfide Deposits. Ore Geology Reviews, 23, 183-222. https://doi.org/10.1016/S0169-1368(03)00035-0

Edwards, S. (1977). A Modified for Resistivity and IP. Geophysics, 42, 1020-1036. https://doi.org/10.1190/1.1440762

Emsbo, P. (2007). Review of Metalliferous Sediments of the World-Fundamental Theory 
of Deep-Sea Hydrothermal Sedimentation. Economic Geology, 102, 1181-1181. https://doi.org/10.2113/gsecongeo.102.6.1181

Evrard, M. et al. (2018). Geophysical Investigation of the Pb-Zn Deposit of Lontzen-Poppelsberg, Belgium. Minerals, 8, 233. https://doi.org/10.3390/min8060233

Fontboté, L., Kouzmanov, K., Chiaradia, M., \& Pokrovski, G. S. (2017). Sulfide Minerals in Hydrothermal Deposits. Elements, 13, 97-103. https://doi.org/10.2113/gselements.13.2.97

Furman, A., \& Ferre, T. P. A. (2003). A Sensitivity Analysis of Electrical Resistivity Tomography Array Types Using Analytical Element Modeling. Vadose Zone Journal, 2, 416-423. https://doi.org/10.2136/vzj2003.4160

Galley, A. G. (1993). Characteristics of Semi-Conformable Alteration Zones Associated with Volcanogenic Massive Sulphide Districts. Journal of Geochemical Exploration, 48, 175-200. https://doi.org/10.1016/0375-6742(93)90004-6

Ghosh, D. P. (1971). The Application of Linear Filter Theory to the Direct Interpretation of Geoelectrical Resistivity Sounding Measurements. Geophysical Prospecting, 19, 192-217. https://doi.org/10.1111/j.1365-2478.1971.tb00593.x

Gibson, H. L. et al. (2007). The VMS Model: Advances and Application to Exploration Targeting. In B. Milkereit (Ed.), Proceedings of Exploration 07: Fifth Decennial International Conference on Mineral Exploration (pp. 713-730).

Goto, T. et al. (2013). Resistivity Survey of Seafloor Massive Sulfide Areas in the Iheya North Area, off Okinawa, Japan. Proceedings of the 11th SEGJ International Symposium, Yokohama, 18-21 November 2013, 298-301.

https://doi.org/10.1190/segj112013-075

Guo, K., Milkreit, B., \& Qian, W. (2014). Geometry Factor for Near Surface Borehole Resistivity Surveys: A Key to Accurate Imaging and Monitoring. In GeoConvention 2014: FOCUS (pp. 1-6).

Guo, W., Dentith, M., \& Zhao, Y. (2000). Geophysical Exploration in the Xi-Cheng Lead-Zinc Orefield, Gansu Province, China. Exploration Geophysics, 31, 243-247. https://doi.org/10.1071/EG00243

Han, M. et al. (2016). Induced Polarization Imaging Applied to Exploration for Low-Sulfidation Epithermal Au-Ag Deposits, Seongsan Mineralized District, South Korea. Journal of Geophysics and Engineering, 13, 817-823. https://doi.org/10.1088/1742-2132/13/5/817

Haroon, A. et al. (2018). Marine Dipole-Dipole Controlled Source Electromagnetic and Coincident-Loop Transient Electromagnetic Experiments to Detect Seafloor Massive Sulphides: Effects of Three-Dimensional Bathymetry. Geophysical Journal International, 215, 2156-2171. https://doi.org/10.1093/gji/ggy398

Hassan, E., Rai, J. K., \& Anekwe, U. O. (2017). Geoelectrical Survey of Ground Water in Some Parts of Kebbi State Nigeria, a Case Study of Federal Polytechnic Bye-Pass Birnin Kebbi and Magoro Primary Health Center Fakai Local Government. Geosciences, 7, 141-149.

Hawke, P. J., \& Brooker, P. I. (2001). Can Sphalerite Be a Polarisable Mineral? An Example from the Century Zn-Pb Deposit. ASEG Extended Abstracts, 2001, 1-4. https://doi.org/10.1071/ASEG2001ab056

Hesse, A., Jolivet, A., \& Tabbagh, A. (1986). New Prospects in Shallow Depth Electrical Surveying for Archaeological and Pedological Applications. Geophysics, 51, 585-594. https://doi.org/10.1190/1.1442113

Hördt, A. et al. (2016). Induced Polarization of Seafloor Massive Sulfides. 4th Interna- 
tional Workshop on Induced Polarization, Aarhus University, Aarhus, 6-8 June 2016, $1-3$.

Idornigie, A., Olorunfemi, M. O., \& Omitogun, A. A. (2006). Electrical Resistivity Determination of Subsurface Layers, Subsoil Competence and Soil Corrositivity at an Engineering Site Location in Akungba-Akoko, South Western Nigeria. Ife. Journal of Science, 8, 159-177. https://doi.org/10.4314/ijs.v8i2.32216

Iijima, K., \& Sayanagi, K. (2013). Resistivity Survey of Seafloor Massive Sulfide Areas in the Iheya North Area, off Okinawa, Japan. Proceedings of the 11th SEGJ International Symposium, Yokohama, 18-21 November 2013, 298-301.

Ishizu, K. et al. (2019). Internal Structure of a Seafloor Massive Sulfide Deposit by Electrical Resistivity Tomography, Okinawa Trough. Geophysical Research Letters, 46, 11025-11034.

Ja, O., Oo, A., \& Arce, J. (2014). Inversion Methodology for Induced Polarization Method of Geophysical Investigation. International Research Journal of Geology and Mining, 4, 51-56.

Johnson, G. R., \& Anderson, L. A. (1981). A Laboratory Study of Some Physical Properties of Sulfide Ores in Igneous and Metamorphic Rocks from the Burnt Nubble Area, Somerset County, Maine. US Department of the Interior, Geological Survey.

Karim, H. H. (2015). Implementation of Electrical Resistivity Imaging (ERI) Technique for Near Surface Investigation. The 2nd International Conference on Buildings, Construction and Environmental Engineering, October 2015, 101-108.

Katsube, T. J. et al. (2003). Bathurst Mining Camp: Implications for Airborne Conductivity Interpretation. Economic Geology, 11, 861-877.

Komori, S. et al. (2017). Depth Profiles of Resistivity and Spectral IP for Active Modern Submarine Hydrothermal Deposits: A Case Study from the Iheya North Knoll and the Iheya Minor Ridge in Okinawa Trough, Japan. Earth, Planets and Space, 69, Article No. 114. https://doi.org/10.1186/s40623-017-0691-6

Kumar, D. et al. (2016). Integrated Geophysical and Geological Studies for Mineral Prospecting in Betul-Chhindwara Belt (BCB), Central India. Journal Geological Society of India, 87, 383-396. https://doi.org/10.1007/s12594-016-0406-9

Langore, L., Alikaj, P., \& Gjovreku, D. (1989). Achievements in Copper Sulphide Exploration in Albania with IP and EM Methods. Geophysical Prospecting, 37, 975-991. https://doi.org/10.1111/j.1365-2478.1989.tb02243.x

Lau, K. (2000). A Review of Downhole Geophysical Methods for Ground Investigation. Geotechnical Engineering Office, Civil Engineering Department.

Lentz, D. R., \& McCutcheon, S. R. (2006). The Brunswick No. 6 Massive Sulfide Deposit, Bathurst Mining Camp, Northern New Brunswick, Canada: A Synopsis of the Geology and Hydrothermal Alteration System. Exploration and Mining Geology, 15, 1-34.

https://doi.org/10.2113/gsemg.15.3-4.1

Lentz, D. R., Thorne, K. G., \& Beal, K.-L. (2009). International Applied Geochemistry Symposium.

Loke, M. H. (2011). Tutorial: 2-D and 3-D Electrical Imaging Surveys B. Malaysia: Geotomo Software.

Loke, M. H. et al. (2013). Recent Developments in the Direct-Current Geoelectrical Imaging Method. Journal of Applied Geophysics, 95, 135-156.

https://doi.org/10.1016/j.jappgeo.2013.02.017

Loke, M. H., \& Barkert, R. D. (1995). Least-Squares Deconvolution of Apparent Resistivity Pseudosections. Geophysics, 60, 1682-1690. https://doi.org/10.1190/1.1443900 
Madsen, L. M., Fiandaca, G., Christiansen, A. V., \& Auken, E. (2018). Resolution of Well-Known Resistivity Equivalences by Inclusion of Time-Domain Induced Polarization Data. Geophysics, 83, E47-E54. https://doi.org/10.1190/geo2017-0009.1

Mammo, T. (2013). Geophysical Models for the Cu-Dominated VHMS Mineralization in Katta District, Western Ethiopia. Natural Resources Research, 22, 5-18. https://doi.org/10.1007/s11053-012-9186-0

McDonald, M. J. et al. (2018). Mineral Assemblages, Textures and in Situ Sulphur Isotope Geochemistry of Sulphide Mineralization from the Cyprus-Type Ice Volcanogenic Massive Sulphide (VMS) Deposit, Yukon, Canada. Minerals, 8, 501. https://doi.org/10.3390/min8110501

Meheni, Y., Guérin, R., Benderitter, Y., \& Tabbagh, A. (1996). Subsurface DC Resistivity Mapping: Approximate 1-D Interpretation. Journal of Applied Geophysics, 34, 255-269. https://doi.org/10.1016/0926-9851(95)00024-0

Meju, M. A. (2002). Geoelectromagnetic Exploration for Natural Resources: Models, Case Studies and Challenges. Surveys in Geophysics, 23, 133-205. https://doi.org/10.1023/A:1015052419222

Milkereit, B. et al. (2008). Geophysical Imaging of a "Blind" Zn-Pb-Ag Deposit. In 70th EAGE Conference and Exhibition incorporating SPE EUROPEC 2008 (pp. 9-12). European Association of Geoscientists \& Engineers. https://doi.org/10.3997/2214-4609.20147628

Moreira, C. A. et al. (2012). Geoelectrical Prospection of Disseminated Sulfide Mineral Occurrences in Camaquã Sedimentary Basin, Rio Grande do Sul State, Brazil. Brazilian Journal of Geophysics, 30, 169-179. https://doi.org/10.22564/rbgf.v30i2.90

Moreira, C. A. et al. (2014). Geological and Geophysical Data Integration for Delimitation of Mineralized Areas in a Supergene Manganese Deposits. Geofísica Internacional, 53, 199-210. https://doi.org/10.1016/S0016-7169(14)71500-4

Morgan, L. A. (2012). Geophysical Characteristics of Volcanogenic Massive Sulfide Deposits. Volcanogenic Massive Sulfide Occurrence Model. US Geological Survey, Reston, $V A, 115,131$.

Ogunbo, J. N. (2018). MATLAB Code for Data-Driven Initial Model of 1D Schlumberger Sounding Curve. Geophysics, 83, F21-F28. https://doi.org/10.1190/geo2016-0631.1

Oldenburg, D. W., \& Li, Y. G. (1994). Inversion of Induced Polarization Data. Geophysical Prospecting, 59, 1327-1341. https://doi.org/10.1190/1.1443692

Olowofela, J. A., Ajani, O. O., \& Oladunjoye, M. A. (2008). Application of Induced Polarization Method to Delineate Sulphide Ore Deposit in Osina Area of Benue State, Nigeria. Ife Journal of Science, 10, 137-150.

Orfanos, C., \& Apostolopoulos, G. (2011). 2D-3D Resistivity and Microgravity Measurements for the Detection of an Ancient Tunnel in the Lavrion Area, Greece. Near Surface Geophysics, 9, 449-457. https://doi.org/10.3997/1873-0604.2011024

Palich, J., \& Qian, W. (2007). EarthProbe: Meeting the Challenges of Gold Exploration through High Resolution Borehole and Surface IP. EarthProbe.

Parasnis, D. S. (1956). The Electrical Resistivity of Some Sulphide and Oxide Minerals and Their Ores. Geophysical Prospecting, 4, 249-278.

https://doi.org/10.1111/j.1365-2478.1956.tb01409.x

Pearce, C. I., Pattrick, R. A. D., \& Vaughan, D. J. (2006). Electrical and Magnetic Properties of Sulfides. In D. J. Vaughan (Ed.), Sulfide Mineralogy and Geochemistry. Reviews in Mineralogy and Geochemistry (Vol. 61, pp. 127-180). De Gruyter.

https://doi.org/10.1515/9781501509490-004 
Pelton, W. H., Rijo, L., \& Swift, C. M. (1978). Inversion of Two-Dimensional Resistivity and Induced-Polarization Data. Geophysics, 43, 788-803. https://doi.org/10.1190/1.1440854

Piercey, S. J., Peter, J. M., \& Herrington, R. J. (2015). Zn-Rich Volcanogenic Massive Sulphide (VMS) Deposits. In S. Archibald, \& S. Piercey (Eds.), Current Perspectives on Zinc Deposits (pp. 37-57). Irish Association for Economic Geology.

Plimer, I. R., \& Finlow-Bates, T. (1978). Relationship between Primary Iron Sulphide Species, Sulphur Source, Depth of Formation and Age of Submarine Exhalative Sulphide Deposits. Mineralium Deposita, 13, 399-410. https://doi.org/10.1007/BF00206573

Qian, W., Milkereit, B., \& Gräber, M. (2007). Borehole Resistivity Tomography for Mineral Exploration. In 69th EAGE Conference and Exhibition incorporating SPE EUROPEC 2007 (pp. 11-14). European Association of Geoscientists \& Engineers. https://doi.org/10.3997/2214-4609.201401607

Qian, W., Milkereit, B., McDowell, G., Stevens, K., \& Halladay, S. (2007). Borehole Resistivity Logging and Tomography for Mineral Exploration. In B. Milkereit (Ed.), Proceedings of Exploration 07: Fifth Decennial International Conference on Mineral EXploration (pp. 1115-1118).

Revil, A., Florsch, N., \& Mao, D. (2015). Induced Polarization Response of Porous Media with Metallic Particles-Part 1: A Theory for Disseminated Semiconductors. Geophysics, 80, D525-D538. https://doi.org/10.1190/geo2014-0577.1

Roach, M., \& Fitzpatrick, A. (2003). The Electrical Properties of the Scuddles VHMS Deposit. ASEG Extended Abstracts, 2003, 1-4. https://doi.org/10.1071/ASEG2003ab143

Robertson, W., \& Hart, J. (2013). Maximising the Use of Induced Polarisation 2D Smooth-Model Inversions. ASEG Extended Abstracts, 2003, 1-4. https://doi.org/10.1071/ASEG2003ab146

Ross, V. (1957). Geochemistry, Crystal Structure and Mineralogy of the Sulfides. Economic Geology, 52, 755-774. https://doi.org/10.2113/gsecongeo.52.7.755

Sáez, R., Pascual, E., Toscano, M. \& Almodóvar, G. R. (1999). The Iberian Type of Volcano-Sedimentary Massive Sulphide Deposits. Mineralium Deposita, 34, 549-570. https://doi.org/10.1007/s001260050220

Samouëlian, A. et al. (2005). Electrical Resistivity Survey in Soil Science: A Review. Soil and Tillage Research, 83, 173-193. https://doi.org/10.1016/j.still.2004.10.004

Scott, J., \& West, G. F. (1969). Induced Polarization of Synthetic, High-Resistivity Rocks Containing Disseminated Sulfides. Geophysics, 34, 87-100. https://doi.org/10.1190/1.1440001

Sharma, S., \& Verma, G. K. (2015). Inversion of Electrical Resistivity Data: A Review. International Journal of Computer and Systems Engineering, 9, 400-406.

Sretenovic, B., \& Arnaut, F. (2019). Inadequacy of 1D, 2D and 3D Resistivity Inverse Modelling in the Presence of Electrical Anisotropy. Earth Sciences, 8, 102-116. https://doi.org/10.11648/j.earth.20190802.14

Sternberg, B. K. (2002). A Review of Some Experience with the Induced-Polarization/Resistivity Method for Hydrocarbon Surveys: Successes and Limitations. Geophysics, 56, 1522-1532. https://doi.org/10.1190/1.1442963

Tavakoli, S., Bauer, T. E. et al. (2016a). Deep Massive Sulphide Exploration Using 2D and 3D Geoelectrical and Induced Polarization Data in Skellefte Mining District, Northern Sweden. Geophysical Prospecting, 1-18.

Tavakoli, S., Thunehed, H. et al. (2016b). Targeting VMS Ore Deposits within the Upper 
$1.5 \mathrm{~km}$ of the Crust in the Central Skellefte District, Northern Sweden, Using 2D and 3D-Resistivity/IP Data. Journal of Geophysical Prospecting.

Telford, W. M. et al. (1990a). Applied Geophysics. Cambridge: Cambridge University Press.

Telford, W. M., Geldart, L. P., \& Sheriff, R. E. (1990b). Applied Geophysics (2nd ed., p. 760). Cambridge: University of Cambridge. https://doi.org/10.1017/CBO9781139167932

Tivey, M. K. et al. (1995). Deducing Patterns of Fluid Flow and Mixing within the TAG Active Hydrothermal Mound Using Mineralogical and Geochemical Data. Journal of Geophysical Research, 100, 12527-12555. https://doi.org/10.1029/95JB00610

Trudinger, P. A. (1981). Origins of Sulphide in Sediments. Journal of Australian Geology \& Geophysics, 6, 279-285.

Tsourlos, P., Ogilvy, R., Papazachos, C., \& Meldrum, P. (2011). Measurement and Inversion Schemes for Single Borehole-to-Surface Electrical Resistivity Tomography Surveys. Journal of Geophysics and Engineering, 8, 487-497.

https://doi.org/10.1088/1742-2132/8/4/001

Tyne, E. D. (1980). A Review of Mise a la Masse Surveys at Elura. Exploration Geophysicists, 11, 44-45. https://doi.org/10.1071/EG9804044

Vaughan, D. J., \& Corkhill, C. L. (2017). Mineralogy of Sulfides. Elements, 13, 81-87. https://doi.org/10.2113/gselements.13.2.81

Walker, J. A. (2010). Stratigraphy and Lithogeochemistry of Early Devonian Volcano-Sedimentary Rocks Hosting the Nash Creek Zn-Pb-Ag Deposit, Northern New Brunswick. In G. L. Martin, \& E. A. Smith (Eds.), Geological Investigations in New Brunswick for 2009 (pp. 52-97). New Brunswick Department of Natural Resources; Lands, Minerals and Petroleum Division, Mineral Resource Report 2010-1.

Wang, J., \& Strangwayt, D. W. (1981). Induced Polarization in Disseminated Sulfide Ores Containing Elongated Mineralization. Geophysics, 46, 1258.

https://doi.org/10.1190/1.1441264

Ward, S. H. (1988). The Resistivity and Induced Polarization Methods. In Symposium on the Application of Geophysics to Engineering and Environmental Problems (pp. 109-250). Environmental \& Engineering Geophysical Society. https://doi.org/10.4133/1.2921804

Ward, S. H. (1990). Resistivity and Induced Polarization Methods. In S. H. Ward (Ed.), Geotechnical and Environmental Geophysics (pp. 147-190). Investigations in Geophysics No. 5 in SEG. https://doi.org/10.1190/1.9781560802785.ch6

Wells, R. C. (1914). Electric Activity in Ore Deposits. Bulletin 548, U.S. Geological Survey.

White, R. M. S., Collins, S., Denne, R., Hee, R., \& Brown, P. (2001). A New Survey Design for 3D IP Inversion Modelling at Copper Hill. Exploration Geophysics, 32, 152-155. https://doi.org/10.1071/EG01152

Wilkinson, P. B. et al. (2006). Optimization of Array Configurations and Panel Combinations for the Detection and Imaging of Abandoned Mineshafts Using 3D Cross-Hole Electrical Resistivity Tomography. Journal of Environmental and Engineering Geophysics, 11, 213-221. https://doi.org/10.2113/JEEG11.3.213

Wright, P. M., \& Ward, S. H. (1987). Borehole Geophysical Techniques for Defining Permeable Zones in Geothermal Systems. Geothermal Energy: A Milestone Year, 10, 253.

Yang, F. W., \& Ward, S. H. (1985). Single-Borehole and Cross-Borehole Resistivity Ano- 
malies of Thin Ellipsoids and Spheroids. Geophysics, 50, 637-655.

https://doi.org/10.1190/1.1441939

Yoshioka, K., \& Zhdanov, M. S. (2005). Three-Dimensional Nonlinear Regularized Inversion of the Induced Polarization Data Based on the Cole-Cole Model. Physics of the Earth and Planetary Interiors, 150, 29-43. https://doi.org/10.1016/j.pepi.2004.08.034

Zonge, K., Wynn, J. et al. (2014). Chap. 9. Resistivity, Induced Polarization, and Complex Resistivity. In Near-Surface Geophysics Part 1: Concepts and Fundamentals (pp. 265-300). Society of Exploration Geophysicists.

https://doi.org/10.1190/1.9781560801719.ch9 